\title{
RANCANG BANGUN MESIN PENCACAH RUMPUT UNTUK PAKAN TERNAK
}

\author{
Ahmad Hanafie', Muh. Fadhli², dan Ilwan Syahruddin ${ }^{3}$ \\ ${ }^{1}$ Dosen Program Studi Teknik Industri Universitas Islam Makassar, \\ ${ }^{2}$ Dosen Program Studi Teknik Mesin Universitas Islam Makassar, \\ ${ }^{3}$ Mahasiswa Program Studi Teknik Mesin Universitas Islam Makassar.

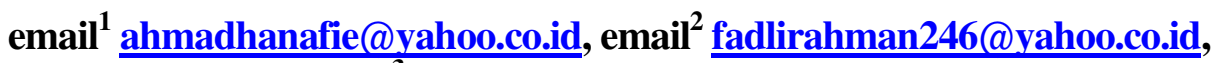 \\ email $^{3}$ ilwansyahruddin@yahoo.co.id
}

\begin{abstract}
ABSTRAK
Peternak setiap hari harus menyediakan rumput dalam jumlah yang cukup banyak untuk dirajang sebagai bahan makan ternak. Peternak di daerah pinrang dan sekitarnya dalam mencacah rumput masih menggunakan sabit. Sehingga apabila rumput dalam jumlah yang cukup banyak maka dibutuhkan waktu dan tenaga yang lebih banyak. Tujuan perancangan mesin pencacah rumput pakan ternak ini adalah, Membuat alat pencacah rumput, dan kapasitas produksi dan efisiensi dari alat pencacah rumput. Data-data yang diperoleh dari hasil pengujian, dianalisis dengan menggunakan metode perbandingan, yaitu dengan membandingkan hasil dari tingkat produktifitas dari alat sebelumnya dengan alat yang telah dibuat. Dengan menggunakan metode ini, dapat diketahui peningkatan atau penurunan dibandingkan dengan alat sebelumnya. Hasil penelitian proses pencacaha mesin pencacah rumput menggunakan pisau berputar dengan menggunakan pisau berbentuk lurus dengan mata pisau berbentuk melengkung,sistem transmisi yang dipilih adalah transmisi tunggal yang terdari dari sepasang pulley berdiamete 5,6 mm untuk pulley motor dan 5,6 mm untuk pulley yang digerakkan. Kapasitas produksi Mesin pencacah rumput setiap 60 menit mampu memotong rumpur sebanyak $69,6 \mathrm{~kg} / \mathrm{jam}$,ketajaman pisau perajang mampu digunakan memotong dalam waktu 10-12 jam/hari,hasil ukuran dan panjang pemotongan rumput seragam.
\end{abstract}

Kata Kunci: Rancangan, kapasitas

\section{PENDAHULUAN}

\subsection{Latar Belakang}

Peternak setiap hari harus menyediakan rumput dalam jumlah yang cukup banyak untuk dirajang sebagai bahan makan ternak. Peternak di daerah pinrang dan sekitarnya dalam mencacah rumput masih menggunakan sabit. Sehingga apabila rumput dalam jumlah yang cukup banyak maka dibutuhkan waktu dan tenaga yang lebih banyak.

Peternak membutuhkan alat bantu agar dalam proses pencacahan atau merajang rumput dapat menghemat waktu dan tenaga yang dikeluarkan. Sehingga dalam merajang atau mencacah diperlukan waktu yang singkat. Jadi sebuah alat pencacah rumput sangat dibutuhkan oleh peternak

Secara umum mesin pencacah rumput terdiri dari motor yang berfungsi sebagai penggerak, sistem transmisi yang berfungsi sebagai sistem pemindah tenaga, casing yang berfungsi untuk melindungi komponen mesin, poros rangka, dan pisau perajang. Hal yang harus diperhatikan dalam pembuatan mesin pencacah rumput gajah adalah bagaimana membuat mesin dan rangka yang kuat, pisaunya tajam sampai beberapa kali 
pemotongan. Mesin atau pencacah makan ternak harus berfungsi secara maksimal sesuai fungsi dan kebutuhannya merupakan hal yang paling harus diperhatikan yaitu efektifnya alat tersebut.

\subsection{Rumusan Masalah}

Dalam perancangan mesin ini, terdapat masalah dalam merancang mesin pencacah rumput pakan ternak adalah sebagai berikut:

1. Bagaimana membuat alat pencacah rumput?

2. Bagaimana mana mengetahui kapasitas produksi dan efesiensi dari alat pencacah rumput.?

\subsection{Tujuan Penelitian}

Bedasarkan rumusan masalah tersebut, maka tujuan perancangan mesin pencacah rumput pakan ternak ini adalah:

1. Membuat alat pencacah rumput,

2. Dengan mengetahui kapasitas produksi dan efisiensi dari alat pencacah rumput.

\subsection{Manfaat Penelitian}

1. Terciptanya mesin ini, diharapkan membantu masyarakat peternak untuk mempermudah proses produksi perajang rumput dengan waktu yang lebih singkat dan tenaga yang lebih efisien.

2. Membantu dalam meningkatkan efektifitas dan efisiensi produksi

\section{METODOLOGI PENELITIAN}

\subsection{Tempat dan Waktu}

a. Perancangan dan pembuatan alat pencacah rumput gajah di laksanakan di laboratotium Universitas Islam Makassar (UIM)

b. Waktu pembuatan alat dilakukan salama 1 bulan di mulai dari bulan Maret, waktu terhitung mulai dari pembuatan alat sampai dengan pengujian alat tersebut.

\subsection{Alat dan Bahan}

\section{Alat}

Berikut ini adalah alat-alat yang diperlukan :

1. Mesin bubut dengan perlengkapannya

2. Mesin gerinda dengan perlengkapannya

3. Mesin las listrik dengan perlengkapannya

4. Mesin bor tangan dengan perlengkapannya

5. Mesin gergaji potong dengan perlengkapannya

6. Mesin pemotong plat

7. Mesin bending plat

\section{Bahan}

Sedangkan bahan-bahan yang diperlukan adalah sebagai berikut :

1. Pengerak Mesin : Motor Listrik

2. Profil Rangka : Profil Siku

3. Sistem Transmisi Sabuk ( V-belt) dengan Puli

4. Poros : Besi

5. Pisau : Persegi Panjang

6. Tempat Pencacahan: Bulat

7. Bantalan (bearing): pillow block bearing

8. Saluran Masuk dan Pengeluaran : Persegi Panjang

9. Casing : Plat Eyzer

10. Penutup komponen berputar Lonjong

11. Bahan Uji : Rumput

\subsection{Langkah Pengujian}

Pengujian mesin pencacah rumput akan dilakukan dengan beberapa tahapan, antara lain :

1. Motor di hidupkan sehingga silinder pemecah berputar dengan kecepatan tertentu tekan tombol ON

2. Rumput yang sudah disediakan dimasukkan kedalam saluran masuk sehingga terjadi proses pencacahan di dalam silinder pencacah yang berputar dengan kecepatan tertentu.

3. Catat berapa waktu yang diperlukan untuk memproduksi pemotongan rumput hingga selesai.

4. Lakukan beberapa kali tahapan diatas sampai didapatkan hasil yang maksimal.

5. Lalu tekan tombol off untuk menghentikan alat. 


\subsection{Metode Analisa Data}

Data-data yang diperoleh dari hasil pengujian, dianalisis dengan menggunakan metode perbandingan, yaitu dengan membandingkan hasil dari tingkat produktifitas dari alat sebelumnya dengan alat yang telah dibuat. Dengan menggunakan metode ini, dapat diketahui peningkatan atau penurunan dibandingkan dengan alat sebelumnya.

\section{ANALISA DAN PEMBAHASAN}

\subsection{Perancangan Mesin Pencacah}

Rancangan mesin pencacah rumput terdiri dari beberapa bagian yaitu rangka. Poros, Pemotong/mata pisau, Rumah mata pisau, Corong, Pulli, dan motor.

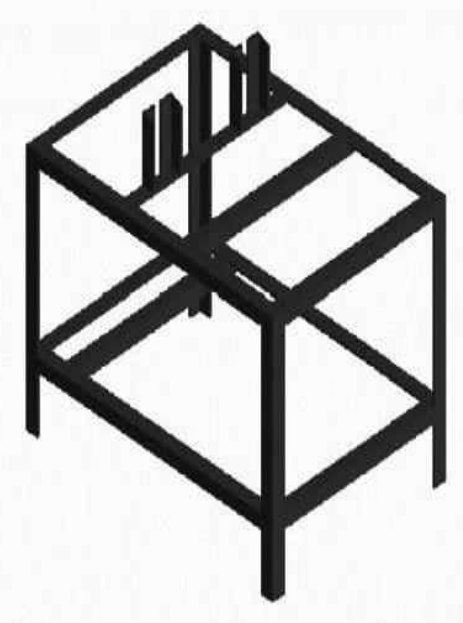

Gambar. 1 Rangka

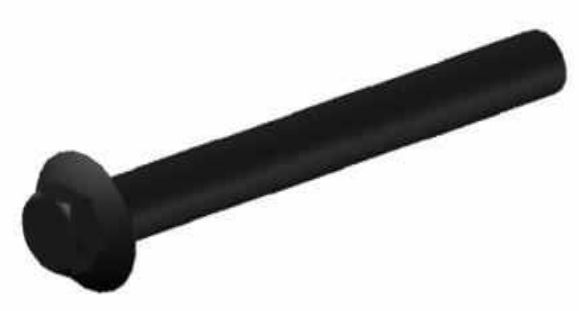

Gambar 2. Poros

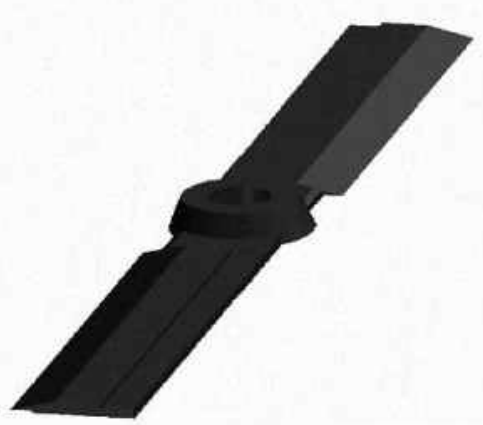

Gambar 3. Pemotong/mata pisau

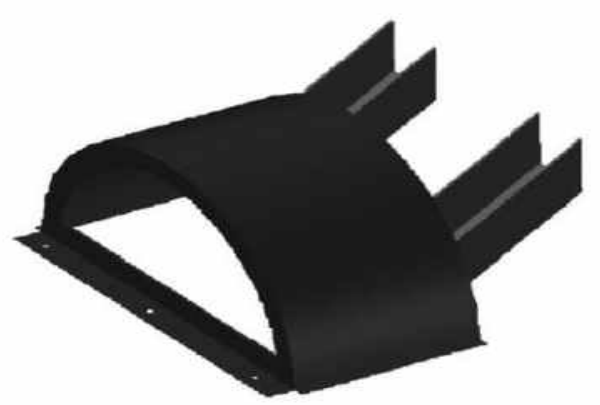

Gambar 4. Rumah Mata Pisau

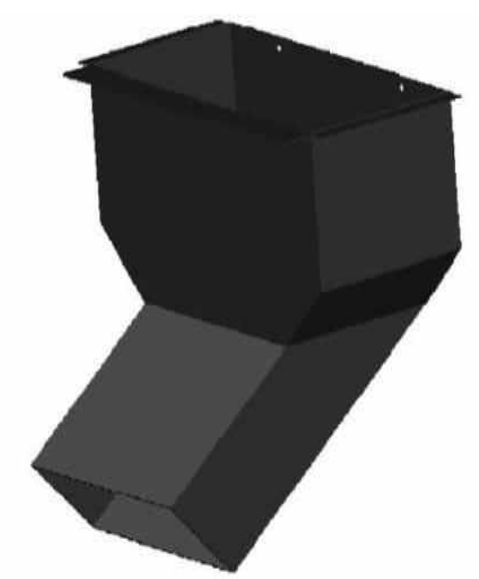

Gambar 5. Corong

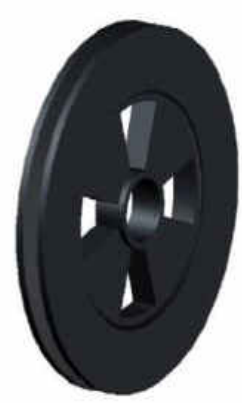

Gambar 6. Pulli 


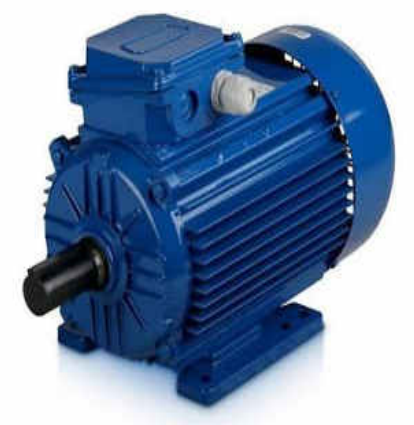

Gambar 7. Motor

\subsection{Pembahasan}

Hasil proses pengujian pengoprasian alat pencacah rumput gajah yang terdiri atas bahan uji yakni bahan rumput yang mampu dicacah sempurna, Data yang telah diproses adalah 1.35 menit $/ \mathrm{kg}$ sehingga dapat dikonversikan dalam kapasitas per jam dengan persamaan Hasil cacahan rumput $(60 \times 1.16 \mathrm{~kg}=69.6 \mathrm{~kg} / \mathrm{jam})$.

Hasil pengujian yang telah dilakukan, maka diperoleh data bahwa perancangan mesin pencacah rumput ini mencapai target dengan hasil $69.6 \mathrm{~kg} / \mathrm{jam}$.

\section{PENUTUP}

\subsection{Kesimpulan}

1. Proses pencacaha mesin pencacah menggunakan pisau berputar, yaitu : dengan menggunakan pisau berbentuk lurus dengan mata pisau berbentuk melengkung,sistem transmisi yang dipilih adalah transmisi tunggal yang terdari dari sepasang pulley berdiamete $5,6 \mathrm{~mm}$ untuk pulley motor dan 5,6 mm untuk pulley yang digerakkan.

2. Kapasitas produksi Mesin pencacah rumput setiap 60 menit mampu memotong rumpur sebanyak 69,6 $\mathrm{kg} / \mathrm{jam}$,ketajaman pisau perajang mampu digunakan memotong dalam waktu 10-12 jam/hari,hasil ukuran dan panjang pemotongan rumput seragam.

\section{DAFTAR PUSTAKA}

Arifyanto, Muhammad. 2009 "Rancang Bangun Mesin Pencacah Rumput Gajah”. Laporan Tugas Akhir. Jurusan Teknik Mesin Universitas Negeri Yogyakarta

Joni Soyalangit, dkk., 2009. Rancang Bangun Mesin Pembuat Chip Kentang Dengan Kafasitas $50 \mathrm{~kg} / \mathrm{Jam}$. Tugas akhir. Makassar: Jurusan TeknikMesinPoliteknikNegeri Ujung Pandang.Tidakditerbitkan

Edward, Josep.1983. Defenisi Tentang Poros, Jakarta Pardjono \& Hantoro, S. (1991). Defenisi Tentang Perhitungan bantalan. Yogyakarta : Liberty

Pasangin,Rio Valentino.2010.”Pengembangan Masin Kripik Singkong "LaporanTugasAkhir.JurusanTehknikMes in Politek Negeri Ujung Pandang .

Smith, H. P. and L.H. Wilkes., 1990. Susunan Khas Sabuk V, Terjemahan T. Purwadi. UGM Presss, Yogyakarta.

Sularso Dan K, Suga, 1991. Dasar Perencanaan dan Pemilihan Elemen Mesin. Pradya Paramitha, Jakarta.

Sularso, 2004. Pengertian Motor Listrik. Pradya Paramitha, Jakarta.

Zainul, Achmad. 1999. Perhitungan Kekuatan Kampuh Las. Skripsi tidak diterbitkan. Malang: Jurusan Teknik Mesin FT Universitas Brawijaya

(http://sutanmuda.wordpress.com/2008/07/22/ budidaya-rumput-gajah-pakanternak/\#more-167) 